\title{
CHLOROQUINE AND RHEUMATOID ARTHRITIS A SHORT-TERM CONTROLLED TRIAL
}

\author{
BY
}

\author{
A. FREEDMAN \\ Hackney Hospital, London
}

(RECEIVED FOR PUBLICATION JUNE 20, 1956)

When Page (1951) reported that mepacrine produced improvement in lupus erythematosus, he stated that, in one of his patients, a rheumatoid type of arthritis which had been present for 2 years improved together with the skin lesions. Following this report, I began an investigation of the treatment of rheumatoid arthritis with mepacrine (Freedman and Bach, 1952). Early results were promising, but a controlled trial was not possible because the drug almost invariably discoloured the skin. A pilot investigation with other antimalarials suggested that Proguanil was of doubtful value, but that chloroquine seemed to give benefit with absence of toxic reactions*. The controlled trial with chloroquine was begun in April, 1953.

\section{Procedure}

Patients. - In order to obtain a sufficient number of patients for the investigation from one rheumatism centre it was unfortunately necessary to include cases which varied considerably as regards duration of disease and extent and severity of joint involvement. A total of 69 patients who showed acute manifestations of the disease which included active inflammation of at least four joints were taken into the trial, and randomly distributed into two groups. One group received chloroquine and the other dummy tablets. These cases were admitted to the trial over a period of 2 years, and the following observations refer to the first 16 weeks of treatment, after which nearly all patients received chloroquine as their standard treatment.

Treatment.-During the trial period all patients received eight 5-gr. tablets of enteric-coated aspirin and $200 \mathrm{mg}$. of ascorbic acid daily. If they were anaemic, oral iron was also prescribed. With regard to the chloroquine or control tablets, the physician did not know which type of treatment each patient was to receive but merely numbered each case in order of the first attendance. The dispenser followed a random list and

* This was reported to the Heberden Society on December 5, 1953 (Annals of the Rheumatic Diseases (1954), 13, 74). dispensed either $\mathbf{Q}$ or $\mathbf{R}$ tablets according to the case number, not knowing which was the active preparation. The first forty patients took one tablet daily, either chloroquine sulphate, $200 \mathrm{mg}$., or the control tablet of similar appearance. Because experience with chloroquine outside the trial suggested that a dose of $300 \mathrm{mg}$. daily was more effective, the remaining patients were given $1 \frac{1}{2}$ tablets daily.

Assessment.-The patients were examined at a special clinic held on a separate afternoon for this purpose. At each visit they were weighed and blood was taken for haemoglobin, erythrocyte sedimentation rate, and liver function tests. They were asked specific questions concerning their mood, appetite, sleep, and strength, their pain and stiffness, and their need for analgesics other than the tablets routinely prescribed. They were asked about any change in their ability to dress and wash, to work, or to carry out household chores and handicrafts. Special note was made of their facies and colour, the presence or absence of oedema of the legs, palmar erythema, Raynaud's phenomenon, nodules, lymph glands, and rashes.

Temporo-mandibular, clavicular, and manubrial joints, and the spine, as well as all the limb joints, were separately examined.

Swelling was assessed arbitrarily in three grades.

Joint tenderness was graded 1, 2, or 3: 1 representing tenderness, 2 wincing, and 3 withdrawal of the affected part. The sum of these tenderness figures was then recorded as total tenderness.

Power of grip was measured on a mercury sphygmomanometer by the patient exerting as much pressure as he could on the folded cuff distended to a pressure of $30 \mathrm{~mm}$. $\mathrm{Hg}$.

The time taken to walk twice the length of a corridor (40 yds) was recorded.

The dexterity of the hands was measured by recording the time taken to insert a lace in and out of the holes on one side of a boot.

The patients were assessed every 2 or 3 weeks. At the end of the trial these records provided figures expressing joint inflammation and joint function, and data from which subjective and objective clinical assessments could be made. 


\section{Material}

There were 35 patients in the control group and 34 in the chloroquine group. In the control group, seven patients defaulted (two at 2 weeks, one at 4 weeks, one at 6 weeks, two at 8 weeks and one at 13 weeks). In the chloroquine group there were no defaulters during the period of the trial. One patient had treatment discontinued at 6 weeks because she developed a psychosis. The omission of all defaulters from the final analysis was thought inadvisable because they were all in the control group and their default might have been due to lack of progress. Therefore, patients who had treatment for 6 weeks or longer-by which time some response would have been apparent-were retained in the groups for analysis.

The final numbers of cases were 32 in the control group and 34 in the chloroquine group, and the age and sex distributions were similar (Table I).

TABLE I

AGE AND SEX DISTRIBUTION

\begin{tabular}{|c|c|c|c|c|c|}
\hline \multirow{2}{*}{ Therapy } & \multirow{2}{*}{$\begin{array}{ll}\cdots & \ldots \\
& \ldots\end{array}$} & \multicolumn{2}{|c|}{ Control } & \multicolumn{2}{|c|}{ Chloroquine } \\
\hline & & Male & Female & Male & Female \\
\hline \multirow{5}{*}{$\begin{array}{c}\text { Age Group } \\
\text { (yrs) }\end{array}$} & $-39 \ldots$ & 2 & 6 & 0 & 5 \\
\hline & $40-49 \ldots$ & 1 & 3 & 4 & 2 \\
\hline & $50-59 \ldots$ & 3 & 9 & 3 & 8 \\
\hline & $60-$ & 3 & 5 & 3 & 9 \\
\hline & All Ages & 9 & 23 & 10 & 24 \\
\hline
\end{tabular}

Table II gives the distribution of patients according to the duration of the disease when treatment was begun. The chloroquine group contained slightly more patients with recent disease. There were eleven patients in the chloroquine group and seven in the control group with disease of less than one year's duration.

TABLE II

DURATION OF DISEASE WHEN TREATMENT WAS BEGUN

\begin{tabular}{|c|c|c|c|c|c|}
\hline \multirow{2}{*}{$\begin{array}{l}\text { Therapy } \\
\text { Sex }\end{array}$} & \multirow{2}{*}{$\frac{\cdots}{\cdots}$} & \multicolumn{2}{|c|}{ Control } & \multicolumn{2}{|c|}{ Chloroquine } \\
\hline & & Male & Female & Male & Female \\
\hline \multirow{4}{*}{$\begin{array}{l}\text { Duration } \\
\text { of Disease } \\
\text { (yrs) }\end{array}$} & Less than 1 & 4 & 3 & 7 & 4 \\
\hline & $1-4$ & 5 & 7 & 2 & 9 \\
\hline & $5-9$ & 1 & 3 & 1 & 6 \\
\hline & $10-$ & 0 & 9 & 0 & 5 \\
\hline
\end{tabular}

For various reasons (holidays, non-attendance, late default, etc.), the duration of the trial period of treatment was not always the 16 weeks originally planned. Table III gives the distribution of the duration of treatment in the two groups. The chloroquine group, on the average, received longer treatment than the control group, the mean being 16 weeks for the former and 14.9 weeks for the latter.

TABLE III

DURATION OF TREATMENT

\begin{tabular}{|c|c|c|c|c|}
\hline Therapy & . & $\ldots$ & Control & Chloroquine \\
\hline \multirow{6}{*}{$\begin{array}{c}\text { Duration } \\
\text { of } \\
\text { Treatment } \\
\text { (wks) }\end{array}$} & $6-7$ & $\cdots$ & 1 & 1 \\
\hline & $8-11$ & - & 4 & 1 \\
\hline & $12-15$ & $\cdots$ & 7 & 7 \\
\hline & 16 & 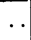 & 20 & 25 \\
\hline & Total & $\ldots$ & 32 & 34 \\
\hline & Average & $\ldots$ & $14 \cdot 9$ & 16 \\
\hline
\end{tabular}

\section{Results}

(a) Joint Tenderness.-Table IV (opposite) recor\& the ranges of joint tenderness at the beginning and end of the treatment. The tenderness decline in both groups but more so in the chloroquine group. Thus, of the seven control patients with total tenderness of less than 10 , only one had lost all tenderness at the end of the trial, whereas of the $\mathbb{\perp}$ four patients with this initial tenderness who $\overrightarrow{\vec{P}}$ received chloroquine, two patients lost all tenderness by the end of the trial. It will also be observed that there were four control patients and nine chloroquine patients with initial tenderness of 30 or more, but at the end of the trial there were five $\bar{\alpha}$ control patients and only one chloroquine patient $\overline{0}$ with this degree of tenderness. The overall averages for joint tenderness at the beginning were 19.0 in 8 the control group and 23.5 in the chloroquine group, falling to $16 \cdot 2$ and $10 \cdot 1$ respectively by the end of the treatment. The mean improvement in the chloroquine group was statistically significant $(t=6.65 ; P<0 \cdot 001)$.

(b) Strength of Grip.-The mean strength for $\mathrm{N}$ the 32 controls at the start of treatment was $134 \cdot 1$, N rising to $139.9 \mathrm{~mm} . \mathrm{Hg}$ at the end of the trial. $\omega$ The figures for the chloroquine-treated group were $129 \cdot 8$, rising to $155 \cdot 3 \mathrm{~mm}$. $\mathrm{Hg}$. The amount of improvement in those receiving chloroquine was statistically significant $(t=5 \cdot 90, P<\cdot 001)$. 
TABLE IV

NUMBER OF PATIENTS WITH GIVEN DEGREE OF TENDERNESS AT END OF COURSE OF TREATMENT RELATED TO INITIAL RANGE OF TENDERNESS

\begin{tabular}{|c|c|c|c|c|c|c|c|c|c|}
\hline \multirow{2}{*}{$\begin{array}{c}\text { Range of } \\
\text { Initial } \\
\text { Tenderness }\end{array}$} & \multirow{2}{*}{\multicolumn{3}{|c|}{ Therapy }} & \multirow{3}{*}{$\frac{\begin{array}{c}\text { No. of } \\
\text { Patients }\end{array}}{7}$} & \multicolumn{5}{|c|}{ Range of Joint Tenderness at End of Course } \\
\hline & & & & & 0 & $1-9$ & $10-19$ & $20-29$ & 30 \\
\hline \multirow[t]{2}{*}{ Less than 10} & Control $\ldots$ & $\cdots$ & $\cdots$ & & 1 & 6 & & & \\
\hline & Chloroquine & $\cdots$ & $\cdots$ & 4 & 2 & 2 & & & \\
\hline \multirow{2}{*}{$10-19$} & Control ... & $\cdots$ & $\cdots$ & 11 & 0 & 6 & 2 & 3 & \\
\hline & Chloroquine & $\cdots$ & $\cdots$ & 10 & 1 & 6 & 2 & 1 & \\
\hline \multirow{2}{*}{$20-29$} & Control $\ldots$ & $\cdots$ & $\cdots$ & 10 & 0 & 2 & 4 & 2 & 2 \\
\hline & Chloroquine & $\cdots$ & $\ldots$ & 11 & 0 & 5 & 4 & 2 & 0 \\
\hline \multirow{2}{*}{$30-$} & Control .. & $\cdots$ & $\cdots$ & 4 & 0 & 0 & 0 & 1 & 3 \\
\hline & Chloroquine & . & . & 9 & 1 & 1 & 4 & 2 & 1 \\
\hline \multirow{2}{*}{ Total } & Control . . & $\cdots$ & $\cdots$ & 32 & 1 & 14 & 6 & 6 & 5 \\
\hline & Chloroquine & . & $\cdots$ & 34 & 4 & 14 & 10 & 5 & 1 \\
\hline
\end{tabular}

TABLE $\mathbf{V}$

NUMBER OF PATIENTS SHOWING GIVEN CHANGE IN STRENGTH OF GRIP (mm./Hg) FROM BEGINNING TO END OF TREATMENT

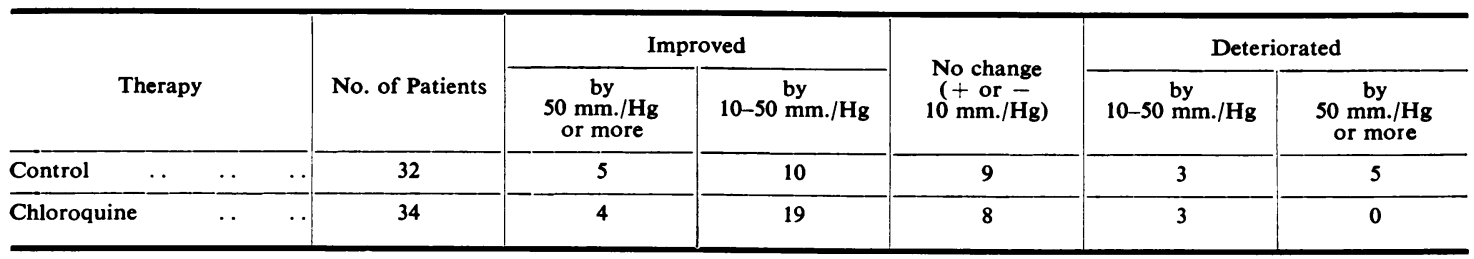

Table $\mathrm{V}$ places the patients according to the degree of improvement or deterioration in strength of grip and illustrates the difference between the two groups.

(c) Function Tests.-Table VI gives the times taken in the lacing and walking tests in the two groups. Only the lacing time of the chloroquinetreated group shows significant improvement, (average improvement $7 \cdot 0, t=4 \cdot 79 ; P<0 \cdot 001$ ). The average walking times for the two groups were not significantly shortened.

TABLE VI

AVERAGE TIME TAKEN TO LACE ONE SIDE OF A BOOT AND TO WALK 40 YARDS

\begin{tabular}{|c|c|c|c|c|}
\hline \multirow{2}{*}{$\begin{array}{c}\text { Ability } \\
\text { Measured }\end{array}$} & \multirow[t]{2}{*}{ Therapy } & \multirow{2}{*}{$\begin{array}{c}\text { Number } \\
\text { of } \\
\text { Patients }\end{array}$} & \multicolumn{2}{|c|}{ Average Time (sec.) } \\
\hline & & & Start & End \\
\hline \multirow{2}{*}{ (a) Lacing* } & Control & 29 & $39 \cdot 0$ & $36 \cdot 4$ \\
\hline & Chloroquine .. & 30 & $39 \cdot 5$ & $32 \cdot 5+$ \\
\hline \multirow{2}{*}{ (b) Walking } & Controlf & 31 & $41 \cdot 8$ & $38 \cdot 4$ \\
\hline & Chloroquine .. & 34 & $44 \cdot 9$ & $41 \cdot 3$ \\
\hline
\end{tabular}

* Not all the patients were so tested.

† Improvement statistically significant.

‡ Excluding one patient who could barely walk the requisite distance. (d) The Score.-A tenderness and function score was obtained by awarding 50 if there was no tenderness (i.e. $\frac{100-0}{2}$ ), 25 if the grip was $200 \mathrm{~mm}$. $\mathrm{Hg}$ or more (i.e. $\frac{200}{8}$ ), and 25 if the walking time was 20 sec. (i.e. $\left.\frac{70-20}{2}\right)$, making a total of 100 , or less if there was tenderness, weakness of grip, or slowness in walking. For example, if a patient had a total tenderness of 24 , a grip of $160 \mathrm{~mm}$. $\mathrm{Hg}$, and a walking time of $40 \mathrm{sec}$, he was awarded $\frac{100-24}{2}+$ $\frac{160}{8}+\frac{70-40}{2}$, i.e. a score of 73 .

Table VII (overleaf) gives the number of patients at different levels at the beginning and end of treatment. Although the chloroquine group started at a rather lower mean level, they finished at a higher mean level than the control group. The mean change for the control group was only $+2 \cdot 4$, while for the chloroquine group there was an improvement of $+11 \cdot 6$, which is statistically significant $(t=7 \cdot 02$; $P<\cdot 001)$. 
TABLE VII

(a) NUMBER OF PATIENTS AT DIFFERENT LEVELS OF SCORE AT THE START AND END OF TREATMENT (b) MEAN SCORE AT START AND END OF TREATMENT

\begin{tabular}{|c|c|c|c|c|c|}
\hline \multirow{2}{*}{$\frac{\text { Therapy }}{\text { No. of Patients }}$} & & \multicolumn{2}{|c|}{ Control } & \multicolumn{2}{|c|}{ Chloroquine } \\
\hline & & At Start & At End & At Start & At End \\
\hline \multirow{4}{*}{$\begin{array}{c}\text { (a) Range of } \\
\text { Score: }\end{array}$} & -59 & 5 & 5 & 11 & 3 \\
\hline & $60-79$ & 17 & 11 & 15 & 13 \\
\hline & \multirow[t]{2}{*}{$80-100$} & 10 & 16 & 8 & 18 \\
\hline & & 32 & 32 & 34 & 34 \\
\hline (b) Mean of Score & . & $73 \cdot 0$ & $75 \cdot 4$ & $67 \cdot 6$ & $79 \cdot 2 *$ \\
\hline
\end{tabular}

* Statistically significant.

(e) Haemoglobin Levels and Blood Sedimentation Rate.-Table VIII gives the average figures at the beginning and end of treatment. Changes were slight and there were no appreciable differences between the two groups.

TABLE VIII

HAEMOGLOBIN AND ERYTHROCYTE SEDIMENTATION RATE

\begin{tabular}{|c|c|c|c|c|}
\hline \multirow{2}{*}{$\begin{array}{c}\text { Character- } \\
\text { istic }\end{array}$} & \multirow{2}{*}{ Therapy } & \multirow{2}{*}{$\begin{array}{c}\text { Number } \\
\text { of } \\
\text { Patients }\end{array}$} & \multicolumn{2}{|c|}{$\begin{array}{c}\text { Average } \\
\text { Measurement }\end{array}$} \\
\hline & & & $\begin{array}{c}\text { Start of } \\
\text { Treatment }\end{array}$ & $\begin{array}{l}\text { End of } \\
\text { Treatment }\end{array}$ \\
\hline \multirow{2}{*}{$\begin{array}{c}\mathrm{Hb} \\
\text { (per cent.) }\end{array}$} & Control & 32 & $78 \cdot 3$ & $79 \cdot 7$ \\
\hline & Chloroquine .. & 34 & $77 \cdot 8$ & $79 \cdot 2$ \\
\hline \multirow{2}{*}{$\begin{array}{c}\text { E.S.R. } \\
\text { (mm./hr } \\
\text { Wintrobe })\end{array}$} & Control & 32 & $36 \cdot 4$ & $34 \cdot 3$ \\
\hline & Chloroquine .. & 34 & $40 \cdot 1$ & $36 \cdot 5$ \\
\hline
\end{tabular}

(f) Clinical Assessment.-Owing to the short period of the trial it was not possible to employ the criteria of the American Rheumatic Association (Steinbrocker, Traeger, and Batterman, 1949) to express the degree of improvement achieved.

The recorded clinical data made it possible to judge the progress of each patient for the period of the trial, and also to give an assessment of the patient's own view of his improvement or deterioration. These objective and subjective impressions are given in Table IX. They show close agreement and indicate a clear advantage to the patients receiving chloroquine. Definite deterioration occurred in five of the control group and in none of the chloroquine group.

(g) Toxic Effects.-One patient receiving chloroquine developed delusions and euphoria after 6 weeks. When the tablets were discontinued the symptoms still persisted; she was an elderly woman and it would seem very unlikely that the chloroquine was responsible.

Eighteen of the control subjects gained weight during the trial period, and twelve lost weight. In the chloroquine-treated group, nine patients gained weight and twenty patients lost weight.

There was thus a mean rise of $1.2 \mathrm{lb}$. in the control group and a mean fall of $1.6 \mathrm{lb}$. in the chloroquine group. Loss of weight is a feature of activity of rheumatoid arthritis, and these figures indicate that the weight was lost while patients were improving on chloroquine, and suggest that the drug was responsible.

In the chloroquine-treated group two patients had a recurrence of eczema that they had had before, one patient had a transient rash on his hands, one had eczema on one leg, and one had some irritation of his hands.

In the control group one patient complained of pruritus, one had a recurrence of eczema, and a third had transient irritating papules on the forearms. In all cases the rash was slight and localized and was not sufficiently troublesome to stop the treatment.

\section{Discussion}

Trial.-Previous experience having suggested that improvement began before the 6 th week of treat-

TABle IX

SUBJECTIVE AND OBJECTIVE IMPRESSIONS OF RESPONSE TO TREATMENT

\begin{tabular}{|c|c|c|c|c|c|c|c|c|c|c|}
\hline \multirow{2}{*}{ Impression } & \multirow{2}{*}{ Therapy } & \multirow{2}{*}{$\begin{array}{l}\text { Number } \\
\text { of } \\
\text { Patients }\end{array}$} & \multicolumn{8}{|c|}{ Grades of Response to Treatment* } \\
\hline & & & + IV & + III & $+\mathbf{I I}$ & +1 & $\begin{array}{c}\text { in statu } \\
\text { quo }\end{array}$ & $-\mathbf{I}$ & $-\mathbf{I I}$ & - III \\
\hline \multirow{2}{*}{ Subjective } & Control & 32 & 1 & 6 & 5 & 8 & 3 & 4 & 3 & 2 \\
\hline & Chloroquine .. & 34 & 2 & 11 & 13 & 2 & 3 & 3 & 0 & 0 \\
\hline \multirow{2}{*}{ Objective } & Control $\quad \ldots$ & 32 & 1 & 7 & 4 & 4 & 4 & 7 & 3 & 2 \\
\hline & Chloroquine .. & 34 & 2 & 6 & 14 & 8 & 2 & 2 & 0 & 0 \\
\hline $\begin{aligned} * & + \text { IV }= \\
& + \text { III }= \\
& + \text { II }= \\
+ \text { I } & =\end{aligned}$ & $\begin{array}{l}\text { full restoration of } \\
\text { greatly improved. } \\
\text { moderately improv } \\
\text { slightly improved. }\end{array}$ & $\begin{array}{l}\text { unction wit } \\
\text { ed. }\end{array}$ & t sym & & $\begin{array}{l}- \text { I } \\
- \text { II } \\
- \text { III }\end{array}$ & $\begin{array}{l}=\mathbf{s} \mathbf{1} \\
=\mathbf{m} \\
=\mathrm{m}\end{array}$ & $\begin{array}{l}\text { ly worse. } \\
\text { rately wors } \\
\text { worse. }\end{array}$ & & & \\
\hline
\end{tabular}

+ III $=$ greatly improved.

$+\mathbf{I}=$ slightly improved

-II $=$ moderately worse. 
ment, 16 weeks was chosen as the trial period for each patient in the hope that clear-cut improvement would take place in that time. Numerical assessment of joint tenderness and of the tests of function, together with subjective and objective clinical assessments, provided the measure of progress. Analysis of the figures for joint tenderness, grip, and lacing time shows that the chloroquine group improved significantly whereas in the control group improvement was slight and not significant. The two groups were not perfectly matched, for it so happened that the chloroquine group contained rather more patients with disease of recent onset, with slightly more active disease (as judged by erythrocyte sedimentation rate, extent of tenderness, and function tests), and a slightly longer period of treatment. These differences taken separately were not significant, but it might be held that taken together they would permit the chloroquine-treated group to make greater progress than the control group within the period of the trial. However, assessment according to the duration of the disease shows that in the control group only patients with disease of less than 6 months duration improved almost as much as the chloroquine-treated patients. Comparison of patients with identical periods of treatment shows a similar difference between response to chloroquine and the control tablets as that seen in the two groups as a whole.

The lack of change in haemoglobin and E.S.R. is attributed to the short period of the trial course of treatment.

Long-Term Therapy.-It must be stressed that the improvement shown in the chloroquine-treated group was only moderate, having taken place gradually during the 16 weeks' period of the trial.

Of the 54 patients who remain under observation, $50^{*}$ received chloroquine after the trial. Of these 43 have become really well; that is, they have no stiffness, and any pain that occurs can reasonably be attributed to use of joints affected by secondary degenerative changes. They have no evidence of joint inflammation, but may have a raised erythrocyte sedimentation rate. They have little or no need for analgesics. Three patients have slight joint inflammation, three were taken off chloroquine fairly early because of lack of adequate response, and one still has active disease despite chloroquine.

* After the trial period of treatment six further patients defaulted: three were not receiving chloroquine,

one was on Butazolidin, having gone directly on to this drug after the control tablets;

one was on chloroquine, having improved;

one after a year on chloroquine when he was quite well.

Two other patients died:

one was the patient with a psychosis, already mentioned;

the other, after a course of control tablets, was given chloroquine but defaulted after 5 weeks, and 6 months later died of nephritis.
Observations of these patients and of others treated outside the trial suggests that $200 \mathrm{mg}$. daily might not be enough to control joint inflammation in all cases. An increase in the dose to $300 \mathrm{mg}$., and rarely to $400 \mathrm{mg}$. daily, may be necessary. Cessation of therapy may lead to a relapse within a few months. This seems more likely to occur if the disease is of long standing. Where the arthritis has been present for a few months only, and erythrocyte sedimentation rate has fallen to normal, relapse has not so far occurred.

Toxic Effects.-Nausea and vomiting and difficulty in visual accommodation have been described as toxic reactions to chloroquine. Though not observed during the trial they were present in some patients during subsequent treatment with chloroquine; in a few it was necessary to reduce the dosage, but treatment with chloroquine was not stopped on this account. Nor was treatment stopped where there was a decline in body weight or in the few patients who had pruritus or a mild limited dermatitis. This minor incidence of sideeffects with chloroquine is in sharp contrast to my experience with mepacrine, where rashes were frequent and severe.

Deaths due to aplastic anaemia have occurred in patients given mepacrine for lupus erythematosus (Sawicky, Kanof, Silverberg, Braitman, and Kalish, 1952; Paton, Riddell, and Strong, 1955). I have knowledge of one patient with rheumatoid arthritis who died of aplastic anaemia after mepacrine treatment, and I had two arthritics who have fortunately recovered. It would seem that patients with arthritis or lupus erythematosus are more susceptible to the development of this dreaded toxic effect than are healthy individuals receiving mepacrine as a prophylactic against malaria. Chloroquine is now preferred in the treatment of lupus erythematosus (Goldman, Cole, and Preston, 1953; Stoughton, 1955).

Rationale.-Haydu (1949) believes that the tissue requirements of adenosine triphosphate (ATP) are increased in rheumatoid arthritis. He believes that chloroquine gives benefit because it inhibits the ATP-ase activity (Haydu, 1954).

My own interest in anti-malarials was due to the tentative notion that they might act as chemotherapeutic agents against a hypothetical organism primarily responsible for the disease-a hypothesis which has yet to be made untenable. I do not know that Hench has shifted away from the statement that he made nearly 20 years ago: "As a practising clinician I have committed myself, with reservations, to the microbic theory" (Hench, 1938). 
Kuzell, Gardner, Fairley, and Tripi (1952) screened a large number of antibiotics and chemotherapeutic agents to determine their value in an experimental arthritis in rats produced by a pleuronomonia-like organism. Mepacrine did not help, but gold, aureomycin, and Pentaquine were beneficial.

Brennecke, Alving, Arnold, Bergenstal, and De Wind (1951) studied Primaquine and three related 8-amino quinolines in the treatment of rheumatoid arthritis and thought that they had anti-rheumatic activity. However, toxic effects were common and they suggested further exploration of this group of compounds. Mepacrine and chloroquine are 4-amino quinoline compounds which in general are less toxic than the 8-amino quinolines.

\section{Summary}

66 patients suffering from active rheumatoid arthritis were allocated at random in almost equal numbers to treatment for 16 weeks with either chloroquine or a similar dummy tablet. Although the two groups were not perfectly matched, there was no significant difference between them in respect of duration or severity of disease. The physician himself was unaware of the type of treatment that each patient was receiving. All the patients were also given $40 \mathrm{gr}$. aspirin daily and appropriate physiotherapy. During the early part of the trial $200 \mathrm{mg}$. chloroquine sulphate was given daily, but later the dose was increased to $300 \mathrm{mg}$. A numerical basis for subjective and objective clinical assessment was devised, and this showed that the control group improved only slightly whereas the group treated with chloroquine made a significant though not substantial improvement. No change was observed in haemoglobin and erythrocyte sedimentation rate, and this was attributed to the shortness of the trial period.

The progress of the patients subsequently treated with chloroquine, fifty in all, was satisfactory. Only one had no clear response, despite long-continued treatment, and three others were taken off the drug early because of lack of adequate response. No toxic effect of any significance was noted in patients treated with $300 \mathrm{mg}$. chloroquine sulphate daily for 2 years.

The trial, though not giving conclusive proof of the long-term value of chloroquine in rheumatoid arthritis, does give sufficient data to warrant a larger investigation.

I wish to thank Dr. Francis Bach, Consultant Rheumatologist to Hackney Hospital, for his interest and for permission to treat his patients.
I am greatly indebted to Dr. J. T. Boyd of the Statistical Research Unit of the Medical Research Council, London School of Hygiene and Tropical Medicine, for his help in planning the investigation and for analysing the results.

I must also thank Sister Joan Hornsby for her diligence in the management of the special clinic.

Messrs. May and Baker, Ltd., kindly provided the special tablets of chloroquine sulphate (Nivaquine) and the control tablets.

\section{REFERENCES}

Brennecke, F. E., Alving, A. S., Arnold, J., Bergenstal, D. M., and De Wind, L. T. (1951). J. Lab. clin. Med., 38, 795

Freedman, A. and Bach, F. (1952). Lancet, $2,321$.

Goldman, L., Cole, D. P., and Preston, R. H. (1953). J. Amer. med. Ass., 152, 1428 .

Haydu, G. G. (1949). Amer. J. occup. Ther., 3, 177.

(1953). Amer. J. med. Sci., 225, 71.

(1954). Rheumatism, 10, 32.

Hench, P. S. (1938). In "A Survey of Chronic Rheumatic Diseases," ed. R. G. Gordon and others, p. 35 . Oxford University Press.

Kuzell, W. C., Gardner, G. M., Fairley, D. M., and Tripi, H. B. (1952). "Rheumatic Diseases": based on "Proc. VII Int. Congr. Rheum. Dis.", p. 409. Saunders, Philadelphia.

Page, F. (1951). Lancet, $2,755$.

Paton, M. D., Riddell, M. J., and Strong, J. A. (1955). Lancet,

Sawicky, H. H., Kanof, N. B., Silverberg, M. G., Braitman, M., and Kalish, B. (1952). J. invest. Derm., 19, 397.

Steinbrocker, O., Traeger, C. H., and Batterman, R. C. (1949). J. Amer. med. Ass., 140, 659.

Stoughton, R. B. (1955). 'Illinois med. J., 107, 299.

\section{La chloroquine et l'arthrite rhumatismale}

\section{RÉsumé}

Soixante-six malades, souffrant d'arthrite rhumatismale évolutive, furent désignés au hasard, en nombres presque égaux, pour être traités durant seize semaines, soit à la chloroquine, soit avec des comprimés similaires factices. Bien que les deux groupes ne fussent pas parfaitement assortis, il n'y avait pas de différence significative entre eux en ce qui concerne la durée ou la sévérité de la maladie. Le médecin lui-même était dans l'ignorance du type de traitement que chaque malade recevait. Tous les malades reçurent aussi 2,6 grammes d'aspirine quotidiennement ainsi que la physiothérapie adéquate. Durant la première partie de l'essai, $200 \mathrm{mg}$. de sulphate de chloroquine furent administrés quotidiennement, mais ensuite la dose fut augmentée jusqu'à $300 \mathrm{mg}$. Une base numérique élaborée pour une évaluation clinique subjective et objective, permit de constater que le groupetémoin ne faisait que des progrès légers alors que le groupe traité à la chloroquine faisait des progrès significatifs, bien que non substantiels. Aucun changement ne fut constaté dans le vitesse de sédimentation érythrocytaire et le taux d'hémoglobine, et ceci fut attribué à la brièveté de la période d'essai.

Le progrès des malades, cinquante en tout, traités par la suite à la chloroquine, fut satisfaisant. Un seul ne réagit pas très nettement, en dépit d'un traitement longtemps poursuivi, et trois autres furent soustraits tôt au traitement en raison de leur faible réaction. Aucun effe toxique de quelque importance ne fut remarqué chez les malades traités quotidiennement, durant deux ans, avec $300 \mathrm{mg}$. de sulphate de chloroquine.

L'essai, bien que ne donnant pas de preuve concluante pour la valeur à long terme de la chloroquine contre l'arthrite rhumatismale, apporte des données suffisantes pour autoriser une investigation plus poussée. 
La cloroquina y la artritis reumatoide

\section{SUMARIO}

Sesenta y seis enfermos con artritis reumatoide activa fueron asignados al azar en números casi iguales al tratamiento durante 16 semanas sea con cloroquina, sea con comprimidos semejantes pero inertes. Aunque estos dos grupos no fueran perfectamente apareados, no hubo diferencia entre ellos respecto a la duración o la severidad de la enfermedad. Hasta el médico ignoraba cual de los tratamientos sus pacientes recibian. Todos los enfermos recibían también 2,6 gramos de aspirina diaria así como adecuada fisioterapia. Durante la primera parte de la investigación la dosis diaria de cloroquina fué $200 \mathrm{mg}$., pero luego la dosis fué aumentada a $300 \mathrm{mg}$. Una base numérica elaborada para una avaluación clínica subjetiva y objetiva, permitió observar que el grupo testigo mejoró un poco, mientras que el grupo tratado con cloroquina manifestó una mejoría significativa aunque no substancial. No se notaron alteraciones en la velocidad de sedimentación eritrocitaria o en las cifras de hemoglobina, atribuyéndose esto a la brevedad del período de investigación.

El progreso de los enfermos, cincuenta en todo, tratados subsiguientemente con cloroquina, fué satisfactorio. Un solo no respondió claramente a pesar de un tramiento prolongado y en tres otros hubo que suspender temprano el tratamiento por falta de respuesta adecuada. No se observaron efectos tóxicos de importancia en enfermos tratados con $300 \mathrm{mg}$. de sulfato de cloroquina diarios durante 2 años.

$\mathrm{La}$ investigación, sin ofrecer pruebas conclusivas acerca del valor de la cloroquina en el tratamiento de plazo largo de la artritis reumatoide, provee sin embargo datos suficientes para justificar estudios ulteriores. 